\title{
Relationship between biospeckle laser technique and firmness of Acrocomia aculeata fruits
}

\author{
Anderson G. Costa ${ }^{1}$, Francisco A. C. Pinto ${ }^{2}$, Roberto A. Braga ${ }^{3}$, Sergio Y. Motoike ${ }^{4}$ \& Luis M. N. Gracia ${ }^{5}$ \\ ${ }^{1}$ Universidade Federal Rural do Rio de Janeiro/Instituto de Tecnologia/Departamento de Engenharia. Seropédica, RJ.E-mail: acosta@ufrrj.br (Corresponding author) \\ ${ }^{2}$ Universidade Federal de Viçosa/Departamento de Engenharia Agrícola. Viçosa, MG. E-mail: facpinto@ufv.br \\ ${ }^{3}$ Universidade Federal de Lavras/Departamento de Engenharia. Lavras, MG. E-mail: robbraga@gmail.com \\ ${ }^{4}$ Universidade Federal de Viçosa/Departamento de Fitotecnia. Viçosa, MG. E-mail: motoike@gmail.com \\ ${ }^{5}$ Universidad de Valladolid/Departament Agriculture and Florestry Enginnering. Valladolid, Spain. E-mail: Imnavas@iaf.uva.es
}

\section{Key words:}

macaw palm

maturation

harvesting

optical techniques

\begin{abstract}
A B S T R A C T
Knowing the maturation of the Acrocomia aculeata (macaw palm) fruit is decisive for harvest to be performed when the fruit has a higher content and quality of oil. There are different approaches to monitor maturation and they can be classified as destructive and non-destructive. Variables obtained by optical instruments have been used to determine maturation stage. The present study evaluated the relationship between the biological activity measured by the optical technique of biospeckle laser and firmness, measured in the Acrocomia aculeata fruit pulp between the $41^{\text {st }}$ and $61^{\text {st }}$ week after flowering. The biological activity was quantified by biospeckle images, while the fruit pulp firmness was determined by digital penetrometer. Correlations between variables were evaluated during maturation and in the senescence of fruits. According to the results, significant correlation between biological activity and firmness was found for both evaluated conditions, demonstrating that biospeckle laser can be an effective non-invasive indicator of Acrocomia aculeate fruit maturation assisting in the determination of the moment of harvest.
\end{abstract}

\section{Palavras-chave:}

macaúba

maturação

colheita

técnicas óticas

\section{Relação entre a técnica do biospeckle laser e a firmeza dos frutos de Acrocomia aculeata}

\begin{abstract}
R E S U M O
O conhecimento da maturação dos frutos de Acrocomia aculeata (macaúba) é determinante para que a colheita seja realizada no momento em que o fruto apresente maior quantidade e qualidade de óleo. Existem diversas abordagens para monitorar a maturação, classificadas como destrutivas e não destrutivas. Variáveis obtidas por instrumentos óticos vêm sendo utilizadas para determinar, de forma não destrutiva, o estádio de maturação. Neste trabalho foram avaliadas a relação entre a atividade biológica mensurada pela técnica ótica do biospeckle laser e a firmeza da polpa dos frutos de Acrocomia aculeata entre as $41^{\text {a }}$ e $61^{\text {a }}$ semanas de maturação, após a florada. A atividade biológica foi quantificada a partir das imagens do biospeckle enquanto a firmeza da polpa dos frutos foi determinada por um penetrômetro digital. Foram avaliadas as correlações entre as variáveis durante a maturação e na senescência dos frutos. A partir dos resultados foi constatada correlação significativa entre atividade biológica e firmeza para as duas condições avaliadas demonstrando que o biospeckle laser pode ser um indicador eficiente não invasivo da maturação dos frutos da Acrocomia aculeata auxiliando na determinação do momento de colheita.
\end{abstract}




\section{INTRODUCTION}

Acrocomia aculeata, popularly known as macaw palm, is considered as a promising crop to compose the Brazilian bioenergetic matrix, since its fruits have high contents of oil with the adequate quality for the production of biofuels (Hiane et al., 2005). Motoike et al. (2013) claim that the efficient use of Acrocomia aculeata for oil extraction is still limited by the scarce information on fruit maturation. According to Mota et al. (2011), physical and chemical parameters obtained in the pulp of Acrocomia aculeata fruits are indicators of the adequate moment for harvest, since this fruit part contains the highest contents of oil.

Characteristics associated with fruit maturation are usually evaluated using instrumental and chemical methods that are destructive and involve manual work (Santos et al., 2013; Stanger et al., 2014). Non-invasive methods are used to classify agricultural products of different varieties, such as those presented by Rabelo et al. (2005), Lorente et al. (2012) and El Kalhed et al. (2016). The optical technique known as biospeckle laser has been widely employed in studies on food quality (Rabal \& Braga, 2008; Chargot et al., 2012; Retheesh et al., 2016).

The quantification of biological activity through biospeckle laser has been correlated with parameters linked to the maturation of fruits and vegetables, such as soluble solids, acidity and firmness (Zdunek et al., 2014; Skic et al., 2016).

Since firmness is a parameter used as indicator of fruit maturation, this study aimed to evaluate the relationship between the biological activity measured by the optical technique of biospeckle laser and pulp firmness of Acrocomia aculeata fruits along the maturation weeks and during the senescence period after harvest.

\section{Material AND Methods}

The fruits used in experiment were collected in an extractive cultivation area without commercial purposes, composed of adult plants of Acrocomia aculeata, with more than 10 years, in reproductive stage, located in the 'Zona da

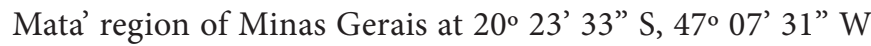
and mean altitude of $601 \mathrm{~m}$.

Ten maturation periods comprehended between the $41^{\text {st }}$ and $61^{\text {st }}$ weeks after flowering (WAF) were evaluated. In each analyzed maturation week, five fruits were collected from 20 different bunches (one bunch in each tree), resulting in 100 fruits per collection. Since it is a region of extractive exploitation, the spacing between trees did not follow a regular distance. The fruits were randomly collected, without taking into consideration its position in each bunch.

Knowing that the maturation of Acrocomia aculeata fruits occurs faster in weeks closer to the harvesting period (Montoya, 2013), the analyses were performed in intervals that were progressively reduced as the fruits approached physiological maturation. Between the first and third collections, there was an interval of four weeks. Between the third and eighth weeks, the interval was two weeks. Then, between the eighth and tenth weeks, the interval was one week.

The reduction in the number of fruits in specific bunches caused by inclement weather, the abortion of some bunches during the experimental period (after the $57^{\text {th }}$ WAF) and the elimination of discrepant values in the subsequent analyses of the maturation variables were responsible for the difference in the number of fruits analyzed in each maturation period, as described in Table 1.

Firmness was determined in the fruit pulp using a digital penetrometer (Instrutherm, model PTR-300) with 5-mmdiameter tip. The values of firmness for each fruit were calculated using the mean of three readings for each fruit, at each moment of analysis.

The apparatus to obtain images using the biospeckle laser technique consisted of a portable microscope (Dino-lite, model AM413ZT) with 1.3-megapixel resolution, a He-Ne laser with power of $50 \mathrm{~mW}$, supports and a set of lenses and intensity-reducing filters. The experimental configuration was backscattering (Rabal \& Braga 2008), which records the scattering of the reflected laser after falling on the sample. The illuminations were performed on fruit pulp (mesocarp) immediately after the removal of the skin (epicarp), as illustrated in Figure 1.

The free software Speckle Tools (Godinho et al., 2012) was used to obtain the images. In each illumination session, 128 successive images of 8 bits relative to the biospeckle patterns were collected in intervals of $0.08 \mathrm{~s}$, with sampling frequency limited to $0-12.50 \mathrm{~Hz}$.

The set of 128 successive images was used to construct a temporal pattern of the speckle, known as Time History Speckle Pattern (THSP), for each fruit (Oulamara et al., 1989).

The variations in the biospeckle pattern intensity were quantified using the method of Difference of Absolute Values

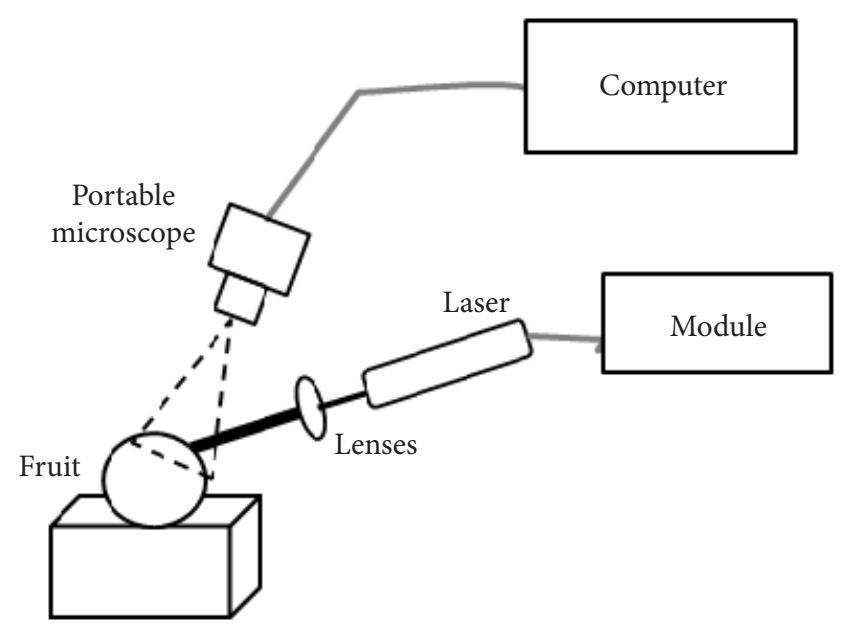

Figure 1. Backscattering experimental configuration to obtain the images from the biospeckle laser

Table 1. Difference in the number of Acrocomia aculeata fruits analyzed in each week after flowering (WAF) caused by inclement weather, abortion of bunches and elimination of discrepant values

\begin{tabular}{cccccccccccc}
\hline WAF & $\mathbf{4 1}$ & $\mathbf{4 5}$ & $\mathbf{4 9}$ & $\mathbf{5 1}$ & $\mathbf{5 3}$ & $\mathbf{5 5}$ & $\mathbf{5 7}$ & $\mathbf{5 9}$ & $\mathbf{6 0}$ & $\mathbf{6 1}$ & Total \\
$\mathrm{N}^{0}$ of fruits & 94 & 93 & 91 & 90 & 83 & 67 & 88 & $\mathbf{7 9}$ & 69 & 69 & 823 \\
\hline
\end{tabular}


(DAV) (Cardoso \& Braga, 2014), which is based on the calculations of THSP intensity variations generated from the biospeckle laser patterns according to Eq. 1. Thus, indices referring to the biological activity (BA) of the pulp of macaw palm fruits were generated.

$$
A B=\sum_{i j}\left(M_{i j} \frac{M_{i j}}{\sum_{i j} M O C_{i j}}|i-j|\right)
$$

where:

$\mathrm{M}_{\mathrm{ij}}$ - normalized value of the co-occurrence matrix at the coordinates $\mathrm{i}$ and $\mathrm{j}$; and,

$\mathrm{MOC}_{\mathrm{ij}}$ - actual value in the co-occurrence matrix in line $\mathrm{i}$ and column j (Arizaga et al., 1999).

The experiment was divided into two moments, the first one evaluated the relationship between firmness and biological activity in the 10 analyzed weeks of maturation, while the second one evaluated the relationship between firmness and biological activity during the period of fruit senescence, after the harvest performed in the $61^{\text {st }}$ WAF. The fruits collected in this stage were considered as at the point of physiological maturation, being at the adequate moment for harvest (Montoya, 2013). Fifty fruits were used for this analysis. Biological activity and firmness were determined during seven days, in intervals of $24 \mathrm{~h}$. On the $7^{\text {th }}$ day, the fruits showed an advanced level of oxidation in the pulp and were considered as totally degraded and without physiological conditions for oil extraction.

In both moments, the relationship between the response of firmness and biological activity was evaluated using regression models, at a significance level of 0.05 . Pearson's coefficient was used to evaluate the correlation between biological activity and firmness in each bunch during the maturation in the senescence period, at a significance level of 0.05 .

\section{Results AND Discussion}

A tendency of reduction of firmness during the maturation period was observed and described by a linear model, which showed $\mathrm{R}^{2}$ of 0.85 (Figure $2 \mathrm{~A}$ ). It was possible to discriminate two specific maturation stages based on the values of firmness. The first stage, comprehended between 41 and 51 WAF, showed firmness values of 79-44 N. The second one, comprehended between 53 and 55 WAF, showed firmness values of 29-14 $\mathrm{N}$. The lowest values of firmness (20-14 N) were found in fruits harvested after the $57^{\text {th }}$ WAF, i.e., closer to the period of physiological maturation. In the evaluation of the response of the biological activity measured by the biospeckle laser (Figure $2 \mathrm{~B})$, this variable tended to increase along the analyzed period of maturation. The linear relationship between biological activity and WAF showed $\mathrm{R}^{2}$ of 0.875 , with significant fit at 0.05 level.

The reduction of fruit pulp firmness during the maturation process is related to changes in the composition of the sugars that form the polysaccharides and in the solubilization of pectic substances constituting the cell wall, resulting in alterations in cell structures and in the consequent softening of the pulp (Chitarra \& Chitarra, 2005; Chen et al., 2015). Thus, the sharp

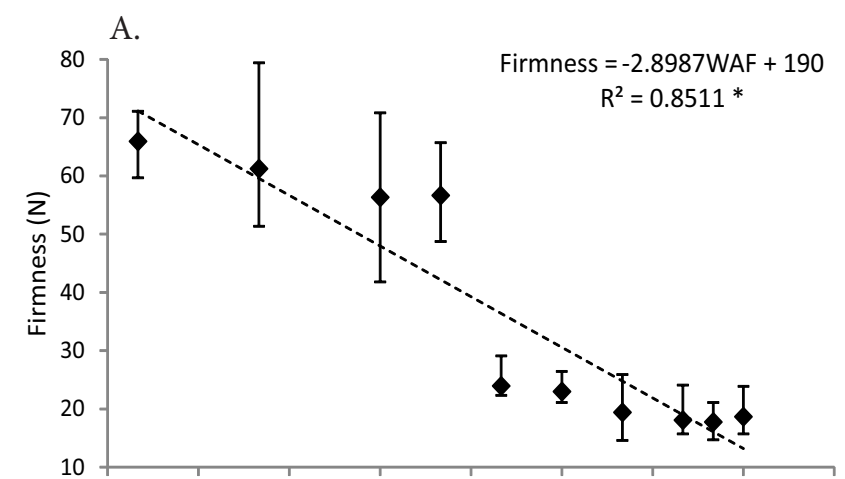

B.

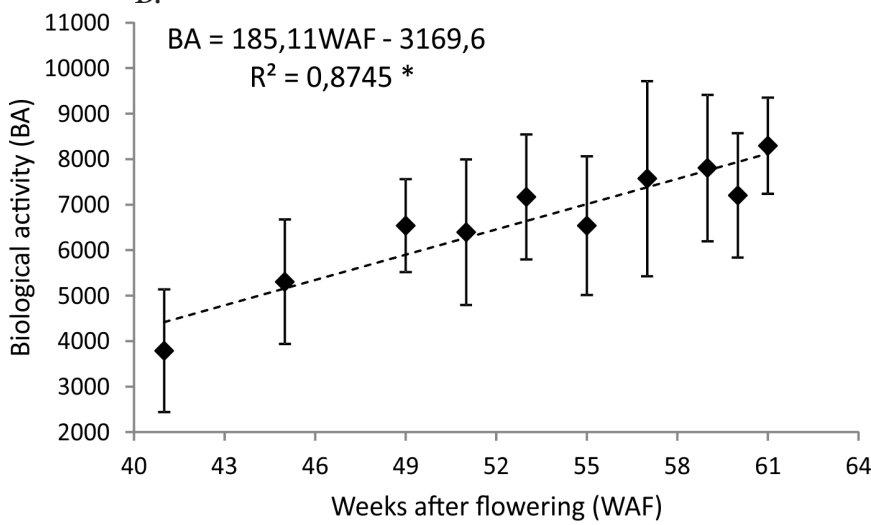

* significant at 0.05 level

Figure 2. Linear relationship between firmness of Acrocomia aculeata fruits and weeks after flowering (A) and between biological activity of Acrocomia aculeata fruits and weeks after flowering with the respective standard deviations in each analyzed week (B)

reduction in the cell cohesion force of the pulp of macaw palm fruits close to physiological maturation may have been the factor responsible for the characterization of two different maturation stages, based on the values of firmness, before and after the $52^{\text {nd }}$ WAF.

The measured biological activity results from the physicochemical variations that occurred inside the cells during fruit development. The increase in biological activity was caused by the metabolic, enzymatic and respiratory activities that occurred during the maturation process (Alves et al., 2013) and generate an intense scattering of the laser.

In the senescence of the fruits after physiological maturation (Figure $3 \mathrm{~A}$ ), there was a sharp reduction in the values of firmness from the fourth day on, demonstrating that determinant alteration in the quality of macaw palm fruits may occur in a more severe way, from this period on. The response of the biological activity (Figure $3 \mathrm{~B}$ ) followed the reduction in fruit pulp firmness along the days of senescence, with tendency of stabilization of the activity between the sixth and the seventh days.

During fruit senescence, ethylene and abscisic acid act together with degradative enzymes that gradually reduce the physiological capacity of the cells due to catabolic processes, cell dehydration and accentuated invasion of microorganisms, resulting in pulp softening (Chitarra \& Chitarra, 2005; Saquet \& Streif, 2012).

The temperature in fruit storage is also a factor that has influence on fruit pulp softening. Kohatsu et al. (2011) 
A.

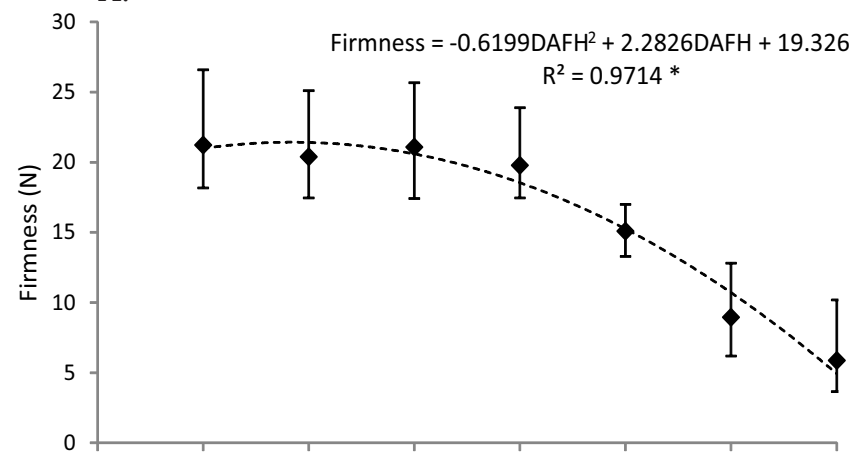

B.

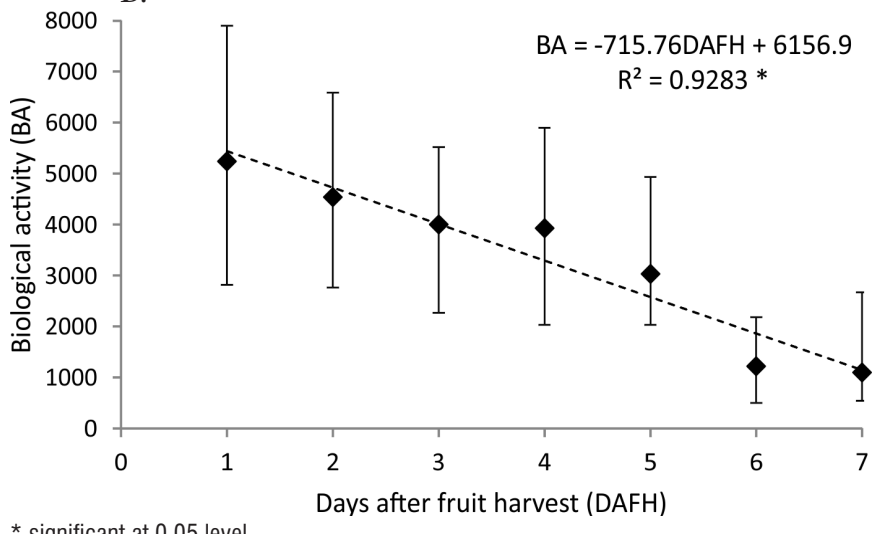

Figure 3. Relationship between firmness of Acrocomia aculeata fruits and the seven days of senescence after harvest in the $61^{\text {st }}$ WAF (DAFH) (A) and biological activity of Acrocomia aculeata fruits and the seven days of senescence after harvest in the $61^{\text {st }} \mathrm{WAF}$ (DAFH) (B)

demonstrated that the pulp firmness of caja fruits suffered a significant reduction on the third day of senescence with the fruit stored at $25^{\circ} \mathrm{C}$, a temperature close to that at which the Acrocomia aculeata fruits were in this experiment $\left(22^{\circ} \mathrm{C}\right)$. The authors also report that the storage at temperatures below $10^{\circ} \mathrm{C}$ retarded the degradative process of the fruits, allowing pulp firmness to remain without significant variations until 6 days.

The decrease in biological activity measured by the biospeckle laser is associated with the reduction in cell activities due to the degradation of the fruits (Zdunek et al., 2014). Physically, the light of the laser absorbed by the plant tissue during the illumination to generate the biospeckle phenomenon is related to the chemical constituents of the fruit, such as pigments, sugar and water (Rabal \& Braga, 2008). Rabelo et al. (2005) quantified the biological activity through biospeckle to indicate the quality of oranges during the senescence of the fruits in post-harvest and also detected reduction in biological activity associated with the loss of quality of the analyzed fruits.

The mean values in each analyzed week of maturation were used to evaluate: correlation between variables, biological activity and firmness, in each bunch (Table 2). There was an inverse correlation (negative correlation) for the fruits of a same bunch, whose increase in biological activity indicated reduction in firmness. Based on the correlation degree analysis of Dancey \& Reidy (2006), 5\% of the sampled bunches showed correlation below 0.30 . On the other hand, $60 \%$ of the bunches showed correlation coefficient between 0.31 and
Table 2. Correlation between biological activity and firmness for each Acrocomia aculeata tree evaluated

\begin{tabular}{lccccc}
\hline & $\mathbf{r}$ & $\mathbf{p}$-value & & $\mathbf{r}$ & $\mathbf{p}$-value \\
Bunch1 & -0.623 & 0.0988 & Bunch11 & -0.594 & 0.1205 \\
Bunch2 & -0.665 & 0.0358 & Bunch12 & -0.626 & 0.0023 \\
Bunch3 & -0.781 & 0.0131 & Bunch13 & -0.581 & 0.1007 \\
Bunch4 & -0.364 & 0.4271 & Bunch14 & -0.839 & 0.0093 \\
Bunch5 & -0.793 & 0.0115 & Bunch15 & -0.719 & 0.0290 \\
Bunch6 & -0.370 & 0.3669 & Bunch16 & -0.126 & 0.7470 \\
Bunch7 & -0.522 & 0.1215 & Bunch17 & -0.306 & 0.3897 \\
Bunch8 & -0.386 & 0.2703 & Bunch18 & -0.517 & 0.1259 \\
Bunch9 & -0.903 & 0.0024 & Bunch19 & -0.762 & 0.0170 \\
Bunch10 & -0.723 & 0.0160 & Bunch20 & -0.642 & 0.0454 \\
\hline
\end{tabular}

0.69 , indicating a moderate correlation, while $35 \%$ showed correlation coefficient higher than 0.70 , indicating strong correlation between the analyzed variables.

In fruit maturation, the significant correlation between firmness of Acrocomia aculeata fruit pulp and biological activity measured through biospeckle in each week after flowering allowed to conclude that, in general, the increase in biological activity is associated with the reduction of firmness (Figure 4A). In the analysis of the relationship between firmness and biological activity during fruit senescence in seven fruits after the harvest in the $61^{\text {st }}$ WAF, there was also a significant correlation between the variables (Figure 4B). However, the highest values of biological activity were associated with the highest values of pulp firmness.

During fruit maturation, the increase in cell volume and intracellular spaces, one of the factors responsible for the reduction in fruit firmness, generates an increment in the
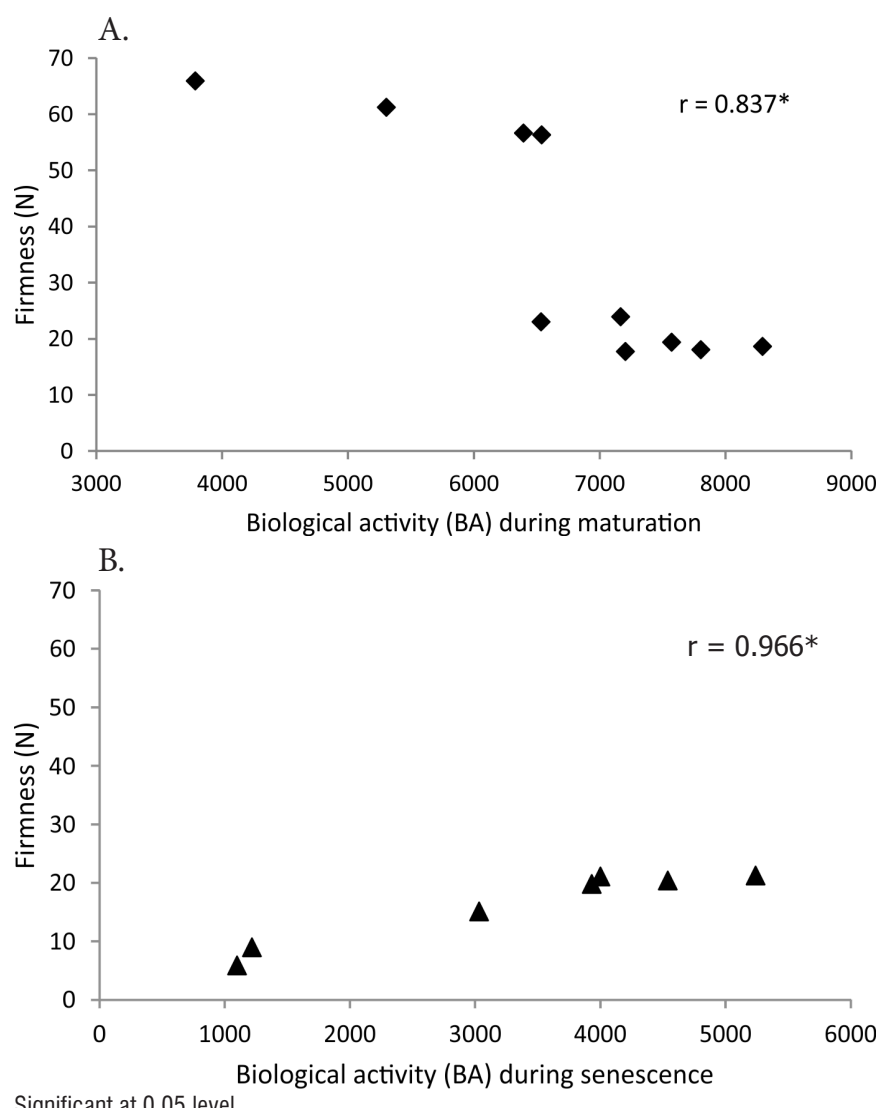

Significant at 0.05 level

Figure 4. Correlation (r) between firmness and biological activity of Acrocomia aculeata fruits during maturation (A) and senescence stage $(B)$ 
activity measured by the biospeckle due to the variation in the scattering of the light not absorbed by the material (Zdunek \& Herppich, 2012). In addition, the degradation of starch in soluble solids during the maturation of Acrocomia aculeata fruits is directly associated with the reduction of firmness and biological activity.

In the post-harvest senescence of the fruits, the reduction of firmness occurs due to the degradation of the cell wall and loss of water, which generate a gradual reduction in cell activities. As already observed in other studies (Zdunek \& Herppich, 2012; Alves et al., 2013), the decrease in fruit metabolism along the days is associated with the reduction of biological activity, demonstrating that the biospeckle laser can be an efficient non-invasive method to monitor the loss of quality of macaw palm fruits during the days after harvest.

Another aspect to be considered is the possible climacteric effect on the Acrocomia aculeata fruits (Goulart, 2014). Climacteric fruits exhibit accentuated increment in the respiratory rate during maturation, which promotes the increase in the metabolic activities, including the production of ethylene, which is one of the agents causing softening in fruit pulp. Therefore, the increase in biological activity and reduction in pulp firmness observed along the development of the fruits and, in a more accentuated way, in the final stages of maturation can also be seen as indication of the climacteric effect on the fruits.

\section{Conclusions}

1. During the weeks of maturation, the increase in biological activity is correlated with the reduction in the firmness of Acrocomia aculeata fruits.

2. In the senescence stage and after the fruits reached physiological maturation, the reduction in biological activity is correlated with the decrease in the firmness of Acrocomia aculeata fruits.

3. The biological activity obtained by the application of the biospeckle laser technique can be considered as an efficient indicator of the maturation of Acrocomia aculeata fruits, assisting in the determination of the moment of harvest.

\section{ACKNOWLEDgMENTS}

To the CNPq (National Council for Scientific and Technological Development), CAPES (Coordination for the Improvement of Higher Education Personnel) and FAPEMIG (Minas Gerais Research Foundation), which partially funded this research.

\section{Literature Cited}

Alves, J. A.; Braga, R. A.; Vilas Boas, E. V. B. Identification of respiration rate and water activity change in fresh-cut carrots using biospeckle laser and frequency approach. Postharvest Biology and Technology, v.86, p.381-386, 2013. https://doi. org/10.1016/j.postharvbio.2013.07.030
Arizaga, R.; Trivi, M.; Rabal, H. Speckle time evolution characterization by the cooccurrence matrix analysis. Optics and Laser Technology, v.31, p.163-169, 1999. https://doi.org/10.1016/S00303992(99)00033-X

Cardoso, R. R.; Braga, R. A. Enhancement of the robustness on dynamic speckle laser numerical analysis. Optics and Lasers in Engineering, v.63, p.19-24, 2014. https://doi.org/10.1016/j. optlaseng.2014.06.004

Chargot, M. S.; Adamiak, A.; Zdunek, A. Pre-harvest monitoring of apple fruits development with the use of biospeckle method. Scientia Horticulturae, v.145, p.23-28, 2012. https://doi. org/10.1016/j.scienta.2012.07.024

Chen, H.; Cao, S.; Fang, X.; Um, H.; Yang, H.; Wang, X.; Xu, Q.; Gao, H. Changes in fruit firmness, cell wall composition and cell wall degrading enzymes in postharvest blueberries during storage. Scientia Horticulturae, v.188, p.44-48, 2015. https://doi. org/10.1016/j.scienta.2015.03.018

Chitarra, M. I. F.; Chitarra, A. B. Pós-colheita de frutos e hortaliças: Fisiologia e manuseio. 2.ed. Lavras: UFLA, 2005. 785p.

Dancey, C.; Reidy, J. Estatística sem matemática para psicologia: Usando SPSS para Windows. Porto Alegre: Artmed, 2006. 608p.

El Khaled, D.; Castellano, N. N.; Gazquez, J. A.; Salvador, R. G.; PereaMoreno, J. A.; Manzano-Agugliaro, F. Dieletric spectroscopy in biometerials: Agrophysics. Materials, v.30, p.310-336, 2016. https://doi.org/10.3390/ma9050310

Goulart, S. M. Amadurecimento pós-colheita de frutos de macaúba e qualidade do óleo para a produção de biodiesel. Viçosa: UFV, 2014. 66p. Dissertação Mestrado

Godinho, R. P.; Silva, M. M.; Braga, R. A. Online biospeckle assessment without loss of definition and resolution by motion history image. Optics and Lasers in Engineering, v.50, p.366-372, 2012. https:// doi.org/10.1016/j.optlaseng.2011.10.023

Hiane, P. A.; Ramos Filho, M. M.; Ramos, M. I. L.; Macedo, M. L. R. Bocaiuva, Acrocomia aculeata (Jacq.) Lodd. pulp and kernel oils: Characterization and fatty acid composition. Brazilian Journal of Food and Technology, v.8, p.256-259, 2005.

Kohastu, D. S.; Zucareli, V.; Brambilla, W. P.; Evangelista, R. M. Qualidade de frutos de cajá-manga armazenado sob diferentes temperaturas. Revista Brasileira de Fruticultura, v.Especial, p.344-349, 2011.

Lorente, D.; Aleixos, N.; Gómez-Sanchis, J.; Cubero, S.; GarcíaNavarrete, O. L.; Blasco, J. Recent advances and applications of hyper spectral imaging for fruit and vegetable quality assessment. Food and Bioprocess Technology, v.5, p.1121-1142, 2012. https://doi.org/10.1007/s11947-011-0725-1

Montoya, S. G. Caracterização do desenvolvimento do fruto da palmeira macaúba. Viçosa: UFV, 2013. 51p.

Mota, C. S.; Corrêa, T. R.; Grossi, J. A. S.; Castricini, A.; Ribeiro, A. S. Exploração sustentável da macaúba para produção de biodiesel: Colheita, pós-colheita e qualidade dos frutos. Informe Agropecuário, v.32, p.41-51, 2011.

Motoike, S. J.; Carvalho, M.; Pimentel, L. D.; Kuki, K. N.; Paes, J. M. V.; Dias, H. C. T.; Sato, A. Y. A cultura da macaúba: Implantação e manejo de cultivos racionais. Viçosa: UFV, 2013. 61p.

Oulomara, G.; Tribillon, J.; Duvernoy, Y. J. Biological activity measurements on botanical specimen surfaces using a temporal the correlation effect of laser speckle. Journal of Moderns Optics, v.36, p.136-179, 1989. 
Rabal, H. J.; Braga, R. A. Dynamic laser speckle and applications. Boca Raton: CRC Press, 2008. 304p. https://doi org/10.1201/9781420060164

Rabelo, G. F.; Braga, R. A.; Fabbro, I. Laser speckle techniques in quality evaluation of orange fruits. Revista Brasileira de Engenharia Agrícola e Ambiental, v.9, p.570-575, 2005. https:// doi.org/10.1590/S1415-43662005000400021

Retheesh, R.; Samuel, B.; Radhakrishnan, P.; Nampoori, V. P. N.; Mujeeb, A. Use of laser biospeckle for the evaluation of fruit ripening. Journal of Pure Applied and Industrial Physics, v.6, p.65-70, 2016.

Santos, J. L.; Resende, E. D.; Martins, D. R.; Gravina, G. D. A.; Cenci, S. A.; Maldonado, J. F. Determinação do ponto de colheita de diferentes cultivares de maracujá. Revista Brasileira Engenharia Agrícola e Ambiental, v.17, p.750-755, 2013. https://doi. org/10.1590/S1415-43662013000700009

Saquet, A. A.; Streif, J. Respiração e produção de etileno de maçãs armazenadas em diversas concentrações de oxigênio. Current Agricultural Science and Technology, v.8, p.71-75, 2012.
Skic, A.; Szymańska-Chargot, M.; Kruk, B.; Chylińska, M.; Pieczywek, P. M.; Kurenda, A.; Zdunek, A.; Rutkowski, K. P. Determination of the optimum harvest window for apples using the non-destructive biospeckle method. Sensors, v.16, p.661-675, 2016. https://doi. org/10.3390/s16050661

Stanger, M. C.; Steffens, C. A.; Amarante, C. V. T.; Corrêa, T. R.; Tanaka, H. Qualidade pós-colheita de ameixas 'camila' e 'laetitia' colhidas em diferentes estádios de maturação. Revista Caatinga, v.27, p.214-221, 2014.

Zdunek, A.; Adamiak, A.; Pieczywek, P. M.; Kurnda, A. The biospeckle method for the investigation of agricultural crops: A review. Optics and Lasers in Engineering, v.52, p.276-285, 2014. https://doi.org/10.1016/j.optlaseng.2013.06.017

Zdunek, A.; Herppich, W. B. Relation of biospeckle activity with chlorophyll content in apples. Postharvest Biology and Technology, v.64, p.58-63, 2012. https://doi.org/10.1016/j. postharvbio.2011.09.007 